\title{
HOW CAN SMALL-SCALE EVENTS CONTRIBUTE TO THE TOURISM PROGRESS OF AN UNDEVELOPED BORDER AREA? LESSON FROM EASTERN SERBIA
}

\author{
Dobrila LUKIĆ \\ Eighth Belgrade Grammar School ,71 Grčića Milenka St., Belgrade 11000, Serbia, e-mail: dobriladjerdap@gmail.com \\ Sunčica STANKOVIĆ \\ Center for Strategic Researching and National Security - Cesna B, 35 Vojvode Vlahovića St., Belgrade 11000, Serbia, e-mail: suncicas372@gmail.com \\ Marko D. PETROVIĆ* \\ Geographical Institute "Jovan Cvijić", Serbian Academy of Sciences and Arts, 9 Djure Jakšića, St., Belgrade 11000, Serbia; South Ural \\ State University, Institute of Sports, Tourism and Service, 76 Lenin Ave., Chelyabinsk 454080, Russia, e-mail: m.petrovic@gi.sanu.ac.rs

\section{Milan M. RADOVANOVIĆ} \\ Geographical Institute "Jovan Cvijić", Serbian Academy of Sciences and Arts, 9 Djure Jakšića, St., Belgrade 11000, Serbia; South Ural \\ State University, Institute of Sports, Tourism and Service, 76 Lenin Ave., Chelyabinsk 454080, Russia, e-mail: m.radovanovic@gi.sanu.ac.rs

\section{Darko VUKOVIĆ} \\ Ural Federal University, Graduate School of Economics and Management, 19 Mira St., Yekaterinburg 620002, Russia; Perm National Research Polytechnic \\ University, Department of Economics and Industrial Engineering, 29 Komsomol'skiy Prospekt, Perm 614990, Russia, e-mail: vukovich@urfu.ru
}

\begin{abstract}
Citation: Lukić, D., Stanković, S., Petrović, M.D., Radovanović, M.M., \& Vuković, D. (2020). HOW CAN SMALL-SCALE EVENTS CONTRIBUTE TO THE TOURISM PROGRESS OF AN UNDEVELOPED BORDER AREA? LESSON FROM EASTERN SERBIA. GeoJournal of Tourism and Geosites, 30(2spl), 905-912. https://doi.org/10.30892/gtg.302spl17-521
\end{abstract}

\begin{abstract}
The study analyses the role and impact of the event "Danube Fair" (Eastern Serbia) in the tourism progress of the less-advantaged border area. The aim of this paper is to emphasize the significance of the role of events in the tourism development of rural settings and the attraction of domestic and foreign visitors with the specific offer of this part of Serbia. The tourism valorization of the event "Danube Fair" was done according to the geographical and economic criteria, and it was determined that it belongs to the category of regional events. In the paper, special attention was paid to the analysis of tourists' satisfaction with this event as a geographical criterion, especially in dependence with the visitors' origin, since it is what the positioning of an event on the tourism market depends on, both on the local and on the international level. "Danube Fair" presents the example of a relatively small-scale event, which can become a basis of tourism growth, with proper valorization and affirmation of local products and services, and their introduction to the international tourism market.
\end{abstract}

Key words: events, tourism development, Golubac Municipality, Podunavlje region, Serbia

\section{INTRODUCTION}

Event tourism represents a significant segment in the overall offer of Serbia. Combined with the natural and anthropogenic tourism values and better tourism presentation and propaganda, it can contribute to tourists' better knowledge of the national tourist offer. At the same time, it can have a positive impact on the construction of new tourism facilities and the reconstruction of old ones, on the structure of accommodation capacities, on the increase in the number of tourism-related services, as well as on the enhancement of the scope of tourist movements on the destination (Hiller, 2000; Dwyer et al., 2005). The negative effects of events as tourism products are unused accommodation capacities, inactivity of tourism organisations, unforeseen losses for organizers, etc. (Olds, 1998; Raj, 2004), as well as the emigration from the community and the increase of the crime (Barker et al., 2002; Presbury and Edwards, 2005). However, event tourism is a type of tourism which can certainly contribute to the improvement in the scope of tourist demand for a certain destination (Bjeljac and Ćurčić, 2003). The purpose of events is to achieve various economic (Hodur and Leistritz, 2007), social (Schlenker et al., 2005; Pasanen et al., 2009; Robertson et al., 2009), ecological (Egresi and Kara, 2014) and other aims. Since tourism is one of the fastest growing industries of the global economy, events have become important elements of the tourist offer (Erfurt and Johnsen, 2003).

In the literature, the dominant topics are the economic impacts of the events on the local population, the analysis primarily of the tourist satisfaction on the destination where the event takes place, the management of the event, and wider impacts of the event primarily on the local population (Moscardo, 2007). The events with the limited duration offer tourists a unique experience, and they can be classified as mega-events to local ones (Egresi and Kara, 2014). The tourists that attend or participate in the event, who travel in groups, and spend more and stay longer on the destination, represent the target market (Tang and Turco, 2001; Gibson et al., 2003), whereas the very destinations where the events take place want to achieve the advantage on the market (Jago et al., 2010). The largest number of researches refers to the researching of mega-events, such as the Olympic Games or World Championships in Football (Boukas et al., 2012; Grix, 2012; Smith, 2014; Bell and Gallimore, 2015; Tichaawa and Bob, 2015). The following are the researches that deal with the events with regional character (O'Brien, 2007; O'Brien and Chalip, 2007), while there is a very small number of researchers who deal with researches of small-scale events (Egresi and Kara, 2014; Kelly and Fairley, 2018; Malchrowicz-Mośko and Poczta, 2018). However, small-scale events could get a more important role as secondary attraction on a destination (Nurse, 2001; McKercher et al., 2006; Alves et al., 2010; Egresi and Kara, 2014).

The greatest attention of domestic and foreign visitors is obtained by the events dedicated to cherishing the tradition, folk customs, folklore, and old crafts. They take place throughout a year, and they are most numerous in summer months. Their main characteristic is the 
ability to attract a large number of visitors and the fast achievement of economic benefits for the destination. Many of them have their regular visitors who want to experience a specific atmosphere, the diversity of cultural contents and folk craftwork (Getz, 2008; Cudny, 2013). According to the program content, they can be divided into: artistic, scientific, economic, sports, religious, political-historical, ethnographical, entertainment, and tourism propaganda. In the recent years, the events that attract most of the attention of domestic and foreign visitors are dedicated to the cherishing of tradition, folk customs, folklore, and old crafts. In order to make an e vent a more successful tourist product, some of its most important elements should be distinguished, such as attractiveness, uniqueness, content, rank, traditionality, quality of organisation and quantity of visitors, venue and connection with natural and anthropogenic tourism values which make up the destination, as well as the period and duration of an event (Bjeljac, 2010). Golubac Municipality (Eastern Serbia) has been more frequently included in the leading tourism destinations of the country and of the wider Podunavlje region (area along the Danube River). Besides land-marking Golubačka tvrđava Fortress, water sports opportunities on the Danube, numerous natural and cultural-historical attractions, the tourist offer of the Golubac Municipality includes events such as the Danube Fair and the Youth Festival. In the period from 25th to 28th July 2019, the 12th Danube Fair was held. It is an event of a collage type with high-quality content which greatly contributes to the enrichment of the cultural life of the community. It belongs to the category of ethnographical events which represent the presentation of folk customs, beliefs, rituals, folklore, and old ways of people's economic activities.

In the recent times, event tourism has been one of the most important types of alternative tourism. Since successful events can contribute to the creation of a destination brand, the attitude of tourists, the visitors of the event on their satisfaction with the tourist experience, can be one of the parameters for measuring the success of an event (Hadžić and Bjeljac, 2006). The aim of this paper is the tourist valorization of the event "Danube Fair" as an important tourist potential of Golubac Municipality, of Serbia, and of the wider Podunavlje region. Tourism is an industry which can have a significant impact on the economic, social, functional and physiognomic structure of rural regions, and it can also represent the reality, needs, and wishes of tourists on one side, and the motion power, the instrument of the development of rural regions on the other side (Woods, 2003). That is why the focus of the research is on the significance of the role of events in the tourism development of rural regions and the attraction of domestic and foreign visitors with the specific offer of this part of Serbia. Besides, the aim of the paper is to present the example of a relatively small-scale event, which can become a nucleus of the tourism development of the local community, with adequate valorization and affirmation of local products and services, and their introduction on the international tourism market.

\section{METHODOLOGY}

In order to perform the tourist valorization of the observed event, in this paper we will use two groups of criteria for the categorization and classification of tourism events in Serbia. The geographical group includes the following: content, the origin of the visitors and participants according to the rank, traditionality, venue, traffic accessibility, time of the year, number of visitors and participants, artistic value of the event, the number of accompanying events, determining the organizer of the event, and visitors' satisfaction (Bjeljac, 2006). This group has the value from zero to five points (Bjeljac, 2006).

The artistic value of an event comprises the assessment of the following: atmosphere, the factors of significance in designing a tourist product, cultural value, robustness and quality of the program content (Bjeljac and Curcic, 2007; Bjeljac, 2010; Bjeljac and Terzic, 2015). From the Hillary du Cross model of tourist valorization (Cross, 2000), the selection of the following indicators has been done for the valorization of tourist events:

- Atmosphere;

Known beyond the local area;

Important national symbol;

It can tell an interesting story;

Its characteristics distinguish it from other anthropogenic goods;

Attractive for special needs;

The event is associated with the culture;

The number of attractive anthropogenic values in the close surroundings;

Educational value;

Historical value;

Social value;

Scientific-research value;

Rarity on the destination and in the region;

The potential for current investments and consultation of the key stakeholders (Bjeljac, 2010).

If the sum of rates for the artistic value of an event is $0-20$, the event has a small tourist value; if it is $21-40$, the event has a medium tourist value, and if the rate sum is $41-60$, the event has a high tourist value. The economic group includes the following: the impact of capital projects, ecological, economic, media, and political impact, stakeholder relations, as well as the assessment of the collaboration with tourism organisations. All the criteria were observed before and after the event, and the scale was from zero to four points (Bjeljac and Ćurčić, 2005; 2007; Bjeljac, 2010; Bjeljac and Terzic, 2015). According to the above mentioned criteria, we can distinguish three categories of events which are attractive for tourist visits, since the sum of the highest values of all the indicators is 116:

- the first category with 97 and more points - events which represent individual tourist value;

- the second category with 73-96 points - events which are an important element of the tourist offer;

- the third category with fewer than 72 points - other events where special attention is paid on the events in underdeveloped regions of Serbia (Bjeljac, 2010).

The research of tourists' opinion on the quality of an event is of great importance, primarily when assessing the life cycle of an event. Namely, the attractiveness of the location, as well as the good position of the location where the event takes place, are greatly influenced by the introduction of new program contents and the continuous improvement of the quality of services related to the event. Tourists' satisfaction with the quality of the event product, i.e. with the success of the event, comprises the assessment of the following factors (Hadžic and Bjeljac, 2006): atmosphere; tourist activity in the region; quality of the event tourism product; the relation between the visitors and the local community; safety during the stay on the destination; and social impact of the event. Atmosphere does not refer only to the immediate surroundings where the event takes place, but also to the experience on the whole destination. It includes natural and cultural goods, design and equipment of green areas, facades, beaches, signs, the existence of cycle paths, etc. (Romelić et al., 2006; Stanojlović et al., 2010). The increase of the tourist attraction of an event is possible due to the higher tourist activity in the region where the event takes place, since the tourists are offered a possibility to form a complex tourist product on the destination (Lukić, 2017). In order to determine the quality of 
services, a model was developed to measure the gap between the expectations regarding the quality of services that a tourist may have before coming to the destination and their perception (rate) of the quality of services after completing their stay on the destination (Parasuraman et al., 1985; 1988; 1991). In order to overcome the problems in the intercultural contacts of guests and hosts, Reisinger (2009) suggested organizing various educational programs, both for tourists and potential hosts. Based on various criteria, the visitors form a perception on the safety of the event venue and the awareness of the local community as a favorable environment for understanding the value of the event, which determines the social impact of the event (Landry, 1994; Wills, 2001). The research has been performed which comprised 223 visitors of the observed event. The sample comprised $48.4 \%$ of the male respondents and 51.6 female respondents. According to the level of education, in the sample, there are no respondents with a lower level of education, $59.2 \%$ have secondary education, and $40.8 \%$ have higher education. Regarding the tourists' origin, $57.4 \%$ of the respondents are from Serbia, whereas $42.6 \%$ of respondents are from abroad.

A survey questionnaire in Serbian and English was used for collecting the data, and the research was performed during the event Danube Fair, from 25th to 28th July 2019. The questionnaire consisted of two parts. The questions in the first part related to the socio-demographic characteristics of the respondents, whereas the second part contained questions related to the satisfaction of the respondents with the tourist product of the event. The respondents expressed the level of their satisfaction (dissatisfaction) on the five-point Likert scale $(1-$ Strongly disagree; 5 - Strongly agree). The analysis of the visitors' satisfaction was observed in correlation with their origin. The research question was assessed using the multivariate analysis of variance (MANOVA). For processing the data, SPSS IBM Statistics Version 21 was used.

\section{RESULTS AND DISCUSSION}

Since the Danube Fair event, according to its content, belongs to the category of ethnographical events (Mackellar, 2006), the main program of the event is "Etno-sabor" (Ethno-gathering), where cultural artistic societies, folklore ensembles and bands take part, and within which an exhibition of folk handicrafts is held in the ethno-yard. The rate of this indicator is 5. Ethnographical events, created on the basis of the memory of the ritual, represent a presentation of folk customs, beliefs, rituals, and old ways of economic activities of the population. They represent the oldest elements in the development of tourism and comprise the elements that make tourists travel, from the wish to learn about the new cultures and civilizations to entertainment, relaxation, etc. (Lukić and Andjelković, 2018).

The criterion which points to the diversity and attractiveness of the program that the event includes in the tourist offer is the number of the accompanying events (Bjeljac, 2006). They enrich the overall program of the event with its entertaining, educational, cultural-artistic, sport, ethnographical, religious, and other contents. The accompanying programs of the Danube Fair in Golubac are the following: National championship and Golubac Cup in sailing, Golubac Pot, the competition in buoy fishing and catfish whisk-fishing, Dragon's village, knightly tournaments, art colony, book promotions, various workshops and concerts. Related to that, the rate of this indicator is 5 , since the number of the accompanying events is higher than 5 . The richness and diversity of the basic and accompanying program is the key factor which put ethnographical events to the first place in the overall tourist offer of Serbia (Bjeljac and Ćurčić, 2010).

To point to the traditionality, i.e. to the continuity of the event organisation, a criterion of the number of years of the event continuity was distinguished. To be traditional, an event has to have an uninterrupted continuity of at least 5 years in a row, with the known date and location (Bjeljac, 2006). In 2019, the Danube Fair was held for the 12th time, so the rate for this indicator is 2, since it belongs to the category of the events with the continuity of 11 to 20 years.

The location where the event takes place is the criterion which points to the connection of the event with the anthropogenic geographical and natural geographical tourist values and is expressed in the distance from the tourist attractive localities (Allen et al., 2002). This criterion represents a significant component of a certain tourist destination. Taking into account that the Danube Fair event is held in Golubac, which is $5 \mathrm{~km}$ away from Golubac Fortress and from the entrance to Đerdap National Park and $9 \mathrm{~km}$ away from the monastery of Tumane, the rate for this indicator is 4 , since it belongs to the category of events with the distance 2 to $10 \mathrm{~km}$ from tourist-related attractive localities.

It is very important whether the event is held in the tourist season, pre-season, during holidays, etc. So, the time when it is held and the number of days of its duration are the criteria which establish the connection of the event with the visitors' free time (Allen, 2000). The duration of an event is most often 1 to 3 days long, but there are those which last for a week or longer. The time and the duration of a tourist event are most frequently in a cause-result relation. The rate for this indicator is 3, since the Danube Fair event in Golubac lasts for four days. Favorable is the time when the event takes place, the last weekend in July, since it is during the summer season of vacations when a large number of visitors is expected.

Table 1. Tourist valorization of the Danube Fair event according to the geographical criteria

\begin{tabular}{|c|c|c|}
\hline \multicolumn{3}{|l|}{ Events according to the content } \\
\hline \multicolumn{2}{|l|}{ Rate scale } & Danube Fair \\
\hline \multicolumn{3}{|l|}{0} \\
\hline \multicolumn{3}{|l|}{1} \\
\hline \multicolumn{3}{|l|}{2} \\
\hline \multicolumn{3}{|l|}{3} \\
\hline \multicolumn{3}{|l|}{4} \\
\hline 5 & & $\mathbf{x}$ \\
\hline \multicolumn{3}{|l|}{ Events according to the traditionality } \\
\hline Continuity & Rate scale & Danube Fair \\
\hline $0-4$ & 0 & \\
\hline $5-10$ & 1 & \\
\hline $11-20$ & 2 & $\mathbf{x}$ \\
\hline $21-30$ & 3 & \\
\hline $31-40$ & 4 & \\
\hline $41+$ & 5 & \\
\hline \multicolumn{3}{|c|}{ Events according to the number of the accompanying events } \\
\hline The number of the accompanying events & Rate scale & Danube Fair \\
\hline 0 & 0 & \\
\hline 1 & 1 & \\
\hline 2 & 2 & \\
\hline 3 & 3 & \\
\hline 4 & 4 & \\
\hline $5+$ & 5 & $\mathbf{x}$ \\
\hline
\end{tabular}




\begin{tabular}{|c|c|c|}
\hline \multicolumn{3}{|c|}{ Events according to the distance from the tourist attractive localities in $\mathrm{km}$} \\
\hline Event venue distance & Rate scale & Danube Fair \\
\hline up to 1 & 5 & \\
\hline $2-10$ & 4 & $\mathbf{x}$ \\
\hline $11-20$ & 3 & \\
\hline $21-30$ & 2 & \\
\hline $31-40$ & 1 & \\
\hline $40+$ & 0 & \\
\hline \multicolumn{3}{|l|}{ Events according to the duration } \\
\hline Event duration in days & Rate scale & Danube Fair \\
\hline 1 & 0 & \\
\hline 2 & 1 & \\
\hline 3 & 2 & \\
\hline 4 & 3 & $\mathbf{x}$ \\
\hline 5 & 4 & \\
\hline $5+$ & 5 & \\
\hline \multicolumn{3}{|c|}{ Events according to the visitors' geographical origin } \\
\hline Visitors' origin & Rate scale & Danube Fair \\
\hline The same settlement or municipality & 0 & \\
\hline Neighboring municipalities & 1 & \\
\hline From the province or region & 2 & \\
\hline From Serbia & 3 & \\
\hline $\begin{array}{l}\text { From the regions of the former Yugoslav } \\
\text { republics and the neighboring countries }\end{array}$ & 4 & $\mathbf{x}$ \\
\hline From abroad & 5 & \\
\hline \multicolumn{3}{|c|}{ Events according to the participants' geographical origin } \\
\hline Participants' origin & Rate scale & Danube Fair \\
\hline The same settlement or municipality & 0 & \\
\hline Neighboring municipalities & 1 & \\
\hline From the province or region & 2 & \\
\hline From Serbia & 3 & $\mathbf{x}$ \\
\hline $\begin{array}{l}\text { From the regions of the former Yugoslav } \\
\text { republics and the neighboring countries }\end{array}$ & 4 & \\
\hline From abroad & 5 & \\
\hline \multicolumn{3}{|l|}{ Events according to the number of visitors } \\
\hline Number of visitors & Rate scale & Danube Fair \\
\hline up to 500 & 0 & \\
\hline $501-1000$ & 1 & \\
\hline $1001-5000$ & 2 & \\
\hline $5001-10,000$ & 3 & \\
\hline $10,001-20,000$ & 4 & $\mathbf{x}$ \\
\hline 20,000 & 5 & \\
\hline \multicolumn{3}{|c|}{ Events according to the number of participants } \\
\hline Number of participants & Rate scale & Danube Fair \\
\hline up to 10 & 0 & \\
\hline $11-50$ & 1 & \\
\hline $51-100$ & 2 & \\
\hline $101-500$ & 3 & \\
\hline $501-1000$ & 4 & \\
\hline over 1000 & 5 & $\mathbf{x}$ \\
\hline \multicolumn{3}{|l|}{ Events according to the artistic value } \\
\hline Rate scale & & Danube Fair \\
\hline \multicolumn{3}{|l|}{0} \\
\hline \multicolumn{3}{|l|}{1} \\
\hline \multicolumn{3}{|l|}{2} \\
\hline \multicolumn{3}{|l|}{3} \\
\hline \multicolumn{3}{|l|}{4} \\
\hline 5 & & $\mathbf{x}$ \\
\hline Events according to the visitors' satisfact & & \\
\hline Rate scale & & Danube Fair \\
\hline 0 & & \\
\hline 1 & & \\
\hline 2 & & \\
\hline 3 & & \\
\hline 4 & & $\mathbf{x}$ \\
\hline 5 & & \\
\hline Event organizers & & \\
\hline Rate scale & & Danube Fair \\
\hline 0 & & \\
\hline 1 & & \\
\hline 2 & & \\
\hline 3 & & \\
\hline 4 & & \\
\hline 5 & & $\mathbf{x}$ \\
\hline
\end{tabular}


The number of visitors and the number of competitors is a criterion which was distinguished with the aim to point to the massiveness and usability of the tourist offer program (Bjeljac, 2010). The rate for the number of visitors is 4 because the number of visitors of this event ranges from 10,000 to 15,000, and the rate for the number of participants is 5 because the number of participants in the Danube Fair in Golubac is over 1000 .

To determine the rank of the event, the important criterion is also the geographical origin of the visitors and participants. The visitors of the Danube Fair in Golubac are mainly from the former Yugoslav countries and Romania, so the rate for this indicator is 4. The participants are from Serbia, so the rate for this indicator is 3.

The one-way multivariate analysis of variance was used to determine the differences between the origin of tourists and their satisfaction with the product of event tourism. The tourists' satisfaction was expressed using six dependent variables: atmosphere, tourist activity in the region, quality of the event tourism product, the relation between the visitors and the local community, safety during the stay on the destination, and the social impact of the event. The independent variable was the tourists' origin (from Serbia or from abroad). The assumption of the homogeneity of the variance and covariance matrix is not violated because the value of Sig, Box's indicator M is 0.035 $>0.001$. The results of MANOVA test are presented in Table 2 .

The preliminary examination assessed the assumptions in the multivariate analysis of variance (normality, linearity, univariate and multivariate non-typical points, variance-covariance homogeneity); serious violation was not noticed (Pallant, 2007; Green and Salking, 2014). There were significant statistical differences between the origin of tourist in comparison with the combination of dependent variables, $\mathrm{F}(6,216)=11.306, \mathrm{p}-$ value $=0.000<0.05 ;$ Wilks' lambda $=0,761 ;$ Partial eta squared $=0.239$ (strong impact) $($ Cohen, 1988, 284-287) .

Table 2. Multivariate tests

\begin{tabular}{|c|c|c|c|c|c|c|c|}
\hline & Effect & Value & $\mathbf{F}$ & Hypothesis df & Error df & Sig. & Partial Eta Squared \\
\hline \multirow[t]{3}{*}{ Intercept } & Pillai's Trace & .984 & 2272.285 & 6.000 & 216.000 & .000 & .984 \\
\hline & Wilks' Lambda & .016 & 2272.285 & 6.000 & 216.000 & .000 & .984 \\
\hline & Hotelling's Trace & 63.119 & 2272.285 & 6.000 & 216.000 & .000 & .984 \\
\hline \multirow{4}{*}{$\begin{array}{l}\text { Tourists' } \\
\text { origin }\end{array}$} & Pillai's Trace & .239 & 11.306 & 6.000 & 216.000 & .000 & .239 \\
\hline & Wilks' Lambda & .761 & 11.306 & 6.000 & 216.000 & .000 & .239 \\
\hline & Hotelling's Trace & .314 & 11.306 & 6.000 & 216.000 & .000 & .239 \\
\hline & Roy's Largest Root & .314 & 11.306 & 6.000 & 216.000 & .000 & .239 \\
\hline
\end{tabular}

Table 3. Tests of between-subjects' effects

\begin{tabular}{|c|c|c|c|c|c|c|c|}
\hline Source & Dependent Variable & $\begin{array}{l}\text { Type III Sum } \\
\text { of Squares }\end{array}$ & df & $\begin{array}{c}\text { Mean } \\
\text { Square }\end{array}$ & $\mathbf{F}$ & Sig. & $\begin{array}{c}\text { Partial Eta } \\
\text { Squared }\end{array}$ \\
\hline \multirow{5}{*}{$\begin{array}{l}\text { Correct } \\
\text { ed } \\
\text { Model }\end{array}$} & Atmosphere & .496 & 1 & .496 & .712 & .400 & .003 \\
\hline & Tourist activity in the region & 9.201 & 1 & 9.201 & 10.935 & .001 & .047 \\
\hline & The relation between the visitors and the local community & .455 & 1 & .455 & .474 & .492 & .002 \\
\hline & Safety during the stay on the destination & .908 & 1 & .908 & 1.066 & .303 & .005 \\
\hline & Social impact of the event & 45.855 & 1 & 45.855 & 62.917 & .000 & .222 \\
\hline \multirow{6}{*}{$\begin{array}{l}\text { Intercep } \\
\mathrm{t}\end{array}$} & Atmosphere & 3684.801 & 1 & 3684.801 & 5283.415 & .000 & .960 \\
\hline & Tourist activity in the region & 2639.694 & 1 & 2639.694 & 3137.153 & .000 & .934 \\
\hline & Quality of the event tourism product & 2736.729 & 1 & 2736.729 & 4696.925 & .000 & .955 \\
\hline & The relation between the visitors and the local community & 3447.020 & 1 & 3447.020 & 3587.854 & .000 & .942 \\
\hline & Safety during the stay on the destination & 3617.213 & 1 & 3617.213 & 4247.331 & .000 & .951 \\
\hline & Social impact of the event & 3192.349 & 1 & 3192.349 & 4380.180 & .000 & .952 \\
\hline \multirow{5}{*}{$\begin{array}{l}\text { Tourists } \\
\text { origin }\end{array}$} & Atmosphere & .496 & 1 & .496 & .712 & .400 & .003 \\
\hline & Tourist activity in the region & 9.201 & 1 & 9.201 & 10.935 & .001 & .047 \\
\hline & Quality of the event tourism product & .729 & 1 & .729 & 1.251 & .265 & .006 \\
\hline & Safety during the stay on the destination & .908 & 1 & .908 & 1.066 & .303 & .005 \\
\hline & Social impact of the event & 45.855 & 1 & 45.855 & 62.917 & .000 & .222 \\
\hline \multirow[t]{6}{*}{ Error } & Atmosphere & 154.132 & 221 & .697 & & & \\
\hline & Tourist activity in the region & 185.956 & 221 & .841 & & & \\
\hline & Quality of the event tourism product & 128.769 & 221 & .583 & & & \\
\hline & The relation between the visitors and the local community & 212.325 & 221 & .961 & & & \\
\hline & Safety during the stay on the destination & 188.213 & 221 & .852 & & & \\
\hline & Social impact of the event & 161.069 & 221 & .729 & & & \\
\hline \multirow[t]{6}{*}{ Total } & Atmosphere & 3909.000 & 223 & & & & \\
\hline & Tourist activity in the region & 2847.000 & 223 & & & & \\
\hline & Quality of the event tourism product & 2914.000 & 223 & & & & \\
\hline & The relation between the visitors and the local community & 3725.000 & 223 & & & & \\
\hline & Safety during the stay on the destination & 3870.000 & 223 & & & & \\
\hline & Social impact of the event & 3356.000 & 223 & & & & \\
\hline \multirow{4}{*}{$\begin{array}{l}\text { Correct } \\
\text { ed Total }\end{array}$} & Atmosphere & 154.628 & 222 & & & & \\
\hline & Tourist activity in the region & 195.157 & 222 & & & & \\
\hline & Safety during the stay on the destination & 189.121 & 222 & & & & \\
\hline & Social impact of the event & 206.924 & 222 & & & & \\
\hline
\end{tabular}

Using another observation of the dependent variable results (Table 2), after the Bonferroni correction of the level of alpha (0,007), the statistical significance was obtained for the differences between the tourists' origin and their satisfaction: tourist activity in the region, $\mathrm{F}$ (1, $221)=4,733, \mathrm{p}=0.001$; Partial eta squared $=0.047$ (small impact), and social impact of the event $\mathrm{F}(1,221)=18.137, \mathrm{p}-\mathrm{value}=0.000$; 
Partial eta squared $=0.222$ (strong impact). The review of the mean values of the results showed that tourists from abroad show slightly higher level of satisfaction regarding the following: tourist activity in the region $(\mathrm{M}=3.68, \mathrm{SD}=1.034)$ compared to the tou rists from Serbia $(\mathrm{M}=3.27, \mathrm{SD}=.82)$; and the social impact of the event $(\mathrm{M}=4.28, \mathrm{SD}=.88)$ compared to the tourists from Serbia $(\mathrm{M}=3.37, \mathrm{SD}=.83)$.

The tourists' satisfaction with the event shown in the previous analysis is a very important criterion which was assessed with rate 4 . The most frequent complaints of the visitors are: fair-like character of the event, the lack of toilet utilities, the lack of parking spaces, etc.

To determine the aim of the event, the important criterion is the event organizers. They include local self-government, governmental and non-governmental organisations, cultural institutions, sport organisations, tourist organisations, legal subjects, etc. (Lukić and Andjelković, 2018). The rate for this indicator is 5, since the organizers of the Danube Fair event are the following: Tourist organisation of Golubac, the Municipality of Golubac, Tourist organisation of Serbia, the Ministry of Commerce, Tourism and Telecommunication, "Veljko Dugošević" library from Golubac, cultural-artistic associations, etc.

Table 4. The valorization of the artistic value of the Danube Fair event according to the modified Hillary du Cross Model (Cross, 2000)

\begin{tabular}{|l|l|}
\hline Indicators & Rate \\
\hline Atmosphere & 5 \\
\hline Known beyond the local area & 3 \\
\hline Important national symbol & 3 \\
\hline It can tell an interesting story & 4 \\
\hline Its characteristics distinguish it from other anthropogenic goods & 5 \\
\hline Attractive for special needs & 5 \\
\hline The event is associated with the culture & 4 \\
\hline The number of attractive anthropogenic values in the close surroundings & 5 \\
\hline Educational value & 3 \\
\hline Historical value & 2 \\
\hline Social value & 4 \\
\hline Scientific-research value & 3 \\
\hline Rarity on the destination and in the region & 5 \\
\hline The potential for current investments and consultation of the key stakeholders & 5 \\
\hline Total & $\mathbf{5 6}$ \\
\hline
\end{tabular}

Based on the total rate of the indicators of the artistic value of the Danube Fair event in Golubac which is 56 (Table 4), it can be concluded that the event has a high tourist value, and thus the rate of the artistic value of the event as a geographical criterion in the event valorization is 5. This is justified by the high rate of atmosphere, the factors significant for designing a tourist product, cultural significance, capacity, and the quality of the program contents. The total rate value of the geographical indicators for the tourist event Danube Fair in Golubac is 49 (Table 1), whereas the total rate value of the economic indicators is 38 (Table 5).

Table 5. Economic group of criteria of the tourist valorization of the Danube Fair event

\begin{tabular}{|c|c|c|c|c|c|}
\hline Number of points & Unsuccessful (0) & Marginal (1) & Good (2) & Very good (3) & Excellent (4) \\
\hline \multicolumn{6}{|l|}{ Capital investments } \\
\hline Before & & & & $\mathbf{x}$ & \\
\hline After & & & $\mathbf{x}$ & & \\
\hline \multicolumn{6}{|l|}{ Ecological criterion } \\
\hline Before & & & & $\mathbf{x}$ & \\
\hline After & & & & $\mathbf{x}$ & \\
\hline \multicolumn{6}{|c|}{ Media-promotional criterion } \\
\hline Before & & & $\mathbf{x}$ & & \\
\hline After & & $\mathbf{x}$ & & & \\
\hline \multicolumn{6}{|c|}{ Socio-political criterion } \\
\hline Before & & & $\mathbf{x}$ & & \\
\hline After & & & $\mathbf{x}$ & & \\
\hline \multicolumn{6}{|l|}{ Economic criterion } \\
\hline Before & & & & $\mathbf{x}$ & \\
\hline After & & $\mathbf{x}$ & & & \\
\hline \multicolumn{6}{|c|}{ Stakeholder relations } \\
\hline Before & & & & & $\mathbf{x}$ \\
\hline After & & & & & $\mathbf{x}$ \\
\hline \multicolumn{6}{|c|}{ Collaboration with tourist organizations } \\
\hline Before & & & & & $\mathbf{x}$ \\
\hline After & & & & & $\mathbf{x}$ \\
\hline
\end{tabular}

Capital investments refer to the built infrastructure related to the needs of tourist event. The rate ranges from very good (3) before the event to good (2) after the event was held. However, these rates will certainly rise in the next period bearing in mind the plan to build a new scene for organizing open-air concerts in Golubac, tennis courts, beaches and other facilities which will greatly contribute to the increase in the number of visitors during the Danube Fair.

Ecological criteria refer to the positive and negative impact of the event on the environment of the region of the venue, i.e. to the level of the environment protection. This indicator was rated as very good (3) for both before and after the event, because of the excellent collaboration of the Tourist organisation of Golubac and the Public utility company of Golubac before and after the Danube Fair. Through the organisation of ecological discussions, the organizers of the event „Danube Fair” could contribute to the future higher awareness among the visitors and participants of the necessity of the environment protection.

Media-promotional impact is a criterion that was rated as good (2) before the event and as marginal (1) after the event was held, since it refers to the presence of the event in the electronic and printed media, promotional activities in the economic meetings and fairs. These indicators are used to determine how strong the impact of the media and promotion on the event organisation is. Due to the fact that the 
Danube Fair in Golubac is promoted on television only during its taking place, through the live reports in certain programs, and on the International Tourism Fair in Belgrade which is held once a year, and on the website and Facebook page of the Tourist organisation of Golubac immediately before the event, these indicators have a relatively low rate.

Since the socio-political criterion refers to the political state in the country where the event is held, and the tourists are given more and more of high-quality national and regional heritage, the event Danube Fair was rated as good (2) for the state before and after the event, because it impacts the creation of the positive attitude of the visitors and participants from abroad about Serbia, and of a better mutual understanding of the population of Serbia.

The economic criterion refers to the direct and indirect financial benefit from the organisation of the event and was rated as good (3) before the Danube Fair, and as marginal (1) after the event organisation because the profit is mostly obtained by the donations, selling souvenirs, renting the stalls, accommodation, bicycles, etc., before and during the event, whereas, what is lacking is the financing from the budget of the local self-government and the state, i.e. of the Ministry of Culture and the Ministry of Regional Development.

Stakeholder relations and the collaboration with tourist organisations got the rate 5 for before and after the Danube Fair in Golubac. They comprise the impact of all the participants in the organisation of the tourist event and have an important role in the development of tourism, bearing in mind that the cooperation of various institutions is necessary for their organisation. As already mentioned, they include tourist organisations, ministries, local community organisations, etc.

\section{CONCLUSION}

The significance of the research of the visitors' opinions on the quality of the event and their overall satisfaction with the tourist experience influences the innovation of the events by introducing new program contents, the improvement of the overall quality of services related to the organisation of the event. It also contributes to its attractiveness in a longer period of time and the good positioning of the destination where the event takes place.

The results of the conducted research point to the existence of significant differences between the satisfaction of the tourists from Serbia and the tourists from abroad with the tourist product of the event, especially with the tourist activity in the region and the social impact of the event. The visitors from Serbia and from abroad point to the higher level of satisfaction regarding the atmosphere, safety during the stay on the destination, and the relation between the visitors and the local community, compared to the tourist activity in the region, the quality of the event tourism product, and the social impact of the event. In the practical sense, the research results point to the fact that in the process of innovation of the event tourism product, as well as in profiling the tourist offer of Golubac Municipality, the satisfaction of visitors regarding all the segments of the product and offer, especially those with the most significant differences should be taken into consideration. Even though ethnographical events in Serbia are mostly of the local character, that is not the case with the Danube Fair in Golubac. The overall rate of the tourist event Danube Fair in Golubac, the sum of all the rates of geographical and economic indicators is 87 . Thus it can be concluded that this event belongs to the category of events which represent a significant element of the tourist offer of the place and the region where it is held. The program of the event also includes the competition in preparing fish stew, so-called Golubac pot, which is similar to the so-called events of 'fish pots' along the Danube in Serbia. For that reason, a sport-cultural-tourist route "The route of fish pots on the Danube in Serbia" could be created. It would connect various aspects of tourism, such as gastronomic tourism, rural tourism, sports tourism, and cultural tourism, since its program would contribute to the preservation of old folk customs, folklore, crafts, economic activities, as well as sport games and various cultural crafts of the rural population in this part of Serbia. In the future, the elements of the event related to the economic group of criteria should be improved - primarily the capital investments, media-promotional criterion, and the economic benefit. It would include better economic effects of the event by expanding the content and the offer which would attract a larger number of visitors and participants, both domestic and from abroad; investments in the traffic infrastructure and tourist substructure; and a better media coverage and fair presentation, both before and after the event is held.

The problems that occurred during this research relate to the possibility of comparing the event Danube Fair with similar ethnographical events outside Serbia. In the available literature, mostly sport events have been analysed, from mega-events to sport events of local character. Also, there is a lack of standardised instrument for the comparison between different events of this type. By removing this shortcoming in the future, the results of this research could be generalized. In the future, the research could also be directed toward the research of the sustainability of event tourism in the border zones and their benefits for the economic and social development of the local community and the protection of the environment in that region. The paper itself encourages further research in terms of innovation and promotion of events in order to emphasise their uniqueness, whereas the limitations of the research lie in a small sample of the questionnaire and the analysis of the tourists' satisfaction with the event based on one criterion - tourists' origin.

The activation of ethnographical events such as „Danube Fair“ would certainly enable the presentation of the cultural heritage of Serbia through learning, connecting and preservation of the tradition, the development of ethnical and cultural identity of the visitors through learning about the past, the development of multicultural character through presenting the foreign visitors with the cultural differences of the peoples in Serbia and, generally, the widening of the cultural insights of the visitors. In the further development of the event, it is necessary to innovate the program of the event in order to improve its attractiveness, preserve the traditional heritage and widen the scope of promotional activities. In that sense, it is necessary to create a network of similar events which would have a joint appearance on the tourism market. It is important to research the motives for visiting this event among the existing tourists, both foreign and domestic, and accordingly change the contents and the overall tourist offer of the destination, i.e. the strategy of the tourism development of this region.

\section{Acknowledgments}

Authors would like to thank Russian Foundation for basic research for the financial support provided within the project No. 17-22-07001-OГH (Complex algorithm for cultural regeneration of minor industrial cities within the context of agglomeration processes in Russia and Europe).

\section{REFERENCES}

Allen, J. (2000). Event Planning, John Wiley, Toronto.

Allen, J., O’Toole, W., McDonnell, I., \& Harris, R. (2002). Festival and special event management (2nd ed.), Wiley, Milton, 608 p.

Alves, H.M.B., Cerro, A.M.C., \& Martins, A.V.F. (2010). Impacts of small tourism events on rural places. Journal of Place Management and Development, 3(1), 22-37.

Barker, M., Page, S.J., \& Meyer, D. (2002). Modeling tourism crime: The 2000 America's cup. Annals of Tourism Research, $29(3), 762-782$.

Bell, B., \& Gallimore, K. (2015). Embracing the games? Leverage and legacy of London 2012 Olympics at the sub-regional level by means of strategic partnerships. Leisure Studies, 34(6), 720-741.

Bjeljac, Ž. (2006). Teorijsko metodološke osnove manifestacionog turizma (Theoretical and methodical bases of event tourism). Geographical Institute "Jovan Cvijić" SASA, Belgrade. 
Bjeljac, Ž. (2010). Turističke manifestacije u Srbiji (Tourism events in Serbia). Geographical Institute "Jovan Cvijić” SASA, Belgrade.

Bjeljac, Ž.N., \& Ćurčić, N.J. (2003). Touristic and propagandic events as a segment of the touristic offer in Vojvodina (province of Serbia). Journal of the Geographical Institute" Jovan Cvijic", SASA, (52), 51-64.

Bjeljac, Ž., \& Ćurčić, N. (2005). Ethnographic events in Vojvodina as part of tourist offer. Geographica Pannonica, (9), 59-64.

Bjeljac, Ž., \& Ćurčić, N. (2007). Turističke manifestacije na prostoru Zapadnog Pomoravlja. Glasnik srpskog geografskog društtva, 87(2), 228-240.

Bjeljac, Ž., \& Ćurčić, N. (2010). Turizmološka valorizacija etnografskih manifestacija u Srbiji. Etnoantropološki problemi, 5(3), $227-242$.

Bjeljac, Ž., \& Terzić, A. (2015). Vukov sabor kao elemenat nematerijalne kulturne baštine u turističkoj ponudi Srbije (Vukov sabor as an element of intangible cultural heritage in tourism offer of Serbia). Issues in Ethnology and Anthropology, 10(2), 507-519.

Boukas, N., Ziakas, V., \& Boustras, G. (2013). Olympic legacy and cultural tourism: Exploring the facets of Athens' Olympic heritage. International Journal of Heritage Studies, 19(2), 203-228.

Cohen, J. (1988). Statistical Power for the Behavioral Science, Lawrence Erlbaum Associates, Hillsdale.

Cros du, H. (2000). Planning for Sustainable Cultural Heritage Tourism in Hong Kong, SAR: Final Report to the Lord Wilson Heritage Trust Council.

Cudny, W. (2013). Festival tourism-the concept, key functions and dysfunctions in the context of tourism geography studies. Geographical Journal, 65(2), $105-118$.

Dwyer, L., Forsyth, P., \& Spurr, R. (2005). Estimating the impacts of special events on an economy. Journal of travel research, 43(4), 351-359.

Egresi, I., \& Kara, F. (2014). Economic and tourism impact of small events: the case of small-scale festivals in istanbul, turkey. Studia Universitatis BabesBolyai, Geographia, 59(1), 47-64.

Erfurt, R.A., \& Johnsen, J. (2003). Influence of an Event on a Destination's Image. Tourism Review, 58(4), 21-27.

Getz, D. (2008). Event tourism: Definition, evolution, and research. Tourism Management, 29(3), 403-428.

Gibson, H.J., Willming, C., \& Holdnak, A. (2003). Small-scale event sport tourism: Fans as tourists. Tourism Management, 24(2), 181-190.

Green, M., \& Salking, N. (2014). Using SPSS for windows and Macintosh: Analyzing and under-standing data, Pearson Education, New York.

Grix, J. (2012). 'Image'leveraging and sports mega-events: Germany and the 2006 FIFA World Cup. Journal of Sport \& Tourism, 17(4), 289-312.

Hadžić, O., \& Bjeljac, Ž. (2006). Ispitivanje faktora koji utiču na zadovoljstvo turističkim doživljajem turiste-posetioca manifestacija u Novom Sadu. Glasnik, 86(2), 261-276.

Hiller, H.H. (2000). Toward an urban sociology of mega-events. Research in Urban Sociology, 5(1), 181-205.

Hodur, N.M., \& Leistritz, F.L. (2007). Estimating the economic impact of event tourism: A review of issues and methods. Journal of Convention \& Event Tourism, 8(4), 63-79.

Jago, L., Dwyer, L., Lipman, G., van Lill, D., \& Vorster, S. (2010). Optimising the potential of mega-events: An overview. International Journal of Event and Festival Management, 1(3), 220-237.

Kelly, D.M., \& Fairley, S. (2018). What about the event? How do tourism leveraging strategies affect small-scale events? Tourism Management, 64, 335-345.

Landry, C. (1994). Measuring Viability and Vitality of City Centre in Urban and Regional Quality of Life Indicators. In Mercer C. (eds.), A Special Publication of the Institute for Cultural Policy Studies, Faculty of Humanities. Brisbane: Griffith University.

Lukić, D. (2017). Evaluation of Immovable Cultural Heritage of Great Importance in Iron Gates as Tourism Destination. (pp. 2-17). In the Second International Thematic Monograph - Thematic Proceedings: Modern Management Tools and Economy of Tourism Sector in Present Era. Belgrade: Association of Economists and Managers of the Balkans in cooperation with the Faculty of Tourism and Hospitality, Ohrid, Macedonia.

Lukić, D., \& Andjelković, S. (2018). Rusallias - A Basis for Promoting Ethno-Tourism in Eastern Serbia. (pp. 701-718). In the Third International Thematic Monograph - Thematic Proceedings: Modern Management Tools and Economy of Tourism Sector in Present Era. Belgrade: Association of Economists and Managers of the Balkans in cooperation with the Faculty of Tourism and Hospitality, Ohrid, Macedonia.

Mackellar, J. (2006). Conventions, festivals, and tourism: Exploring the network that binds. Journal of Convention and Event Tourism, 8(2), 45-56.

Malchrowicz-Mośko, E., \& Poczta, J. (2018). A Small-Scale Event and a Big Impact-Is This Relationship Possible in theWorld of Sport? The Meaning of Heritage Sporting Events for Sustainable Development of Tourism-Experiences from Poland. Sustainability, 10(11), 4289.

McKercher, B., Mei, W.S., \& Tse, T.S.M. (2006). Are short duration cultural festivals tourist attractions? Journal of Sustainable Tourism, 14(1), 55-66.

Moscardo, G. (2007). Analyzing the role of festivals and events in regional development. Event Management, 11(1-2), 23-32.

Nurse, K. (2001). Festival tourism in the Caribbean: An economic impact assessment. Washington, D.C.: Inter-American Development Bank.

O'Brien, D. (2007). Points of Leverage: Maximizing host community benefit from a regional surfing festival. European Sport Management Quarterly, 7(2), 141-165.

O'Brien, D., \& Chalip, L. (2007). 19 sport events and strategic leveraging: Pushing towards the triple bottom line. In A. G. Woodside, \& D. Martin (Eds.), Tourism Management: Analysis, behaviour and strategy (pp. 318-338). Oxford: CABI.

Olds, K. (1998). Urban mega events, evictions and housing rights: The Canadian case. Current Issues in Tourism, 1(1), 2-46.

Pallant, J. (2007). SPSS survival manual - A step by step guide to data analysis using SPSS for windows (3rd ed.). Open University Press, Maidenhead.

Parasuraman, A., Zeithaml, V.A., \& Berry, L.L. (1985). A conceptual model of service quality and its implications for future research. Journal of Marketing, 49(4), 41-50.

Parasuraman, A., Zeithaml, V.A., \& Berry, L.L. (1988). SERVQUAL: A multiple-item scale for measuring consumer perceptions of service quality. Journal of Retailing, 64(1), 12-40.

Parasuraman, A., Zeithaml, V.A., \& Berry, L.L. (1991). Understanding customer expectations of service. Sloan Management Review, 32(3), 39-48.

Pasanen, K., Taskinen, H., \& Mikkonen, J. (2009). Impacts of cultural events in Eastern Finland - Development of a Finnish event evaluation tool. Scandinavian Journal of Hospitality and Tourism, 9(2-3), 112-129.

Presbury, R., \& Edwards, D.C. (2005). Incorporating sustainability in meetings and event management education. International Journal of Event Management Research, 1(1), 30-45.

Raj, R. (2004). The impact of cultural festivals on tourism. Tourism Today, 4, 66-77.

Reisinger, Y. (2009). International Tourism: Cultures and Behavior. London: Taylor \& Francis.

Robertson, M., Rogers, P., \& Leask, A. (2009). Progressing socio-cultural impact evaluation for festivals. Journal of Policy Research in Tourism, Leisure and Events, 1(2), 156-169.

Romelić. J., Pivac. T., \& Košić. K. (2006). Turistička valorizacija starog gradskog jezgra Novog Sada po modelu H. Du Kros (Tourism valorization of the old town center of Novi Sad according to the H. Du Cross model). Glasnik Srpskog geografskog društva, 86(2), 251-260.

Schlenker, K., Edwards, D.C., \& Sheridan, L. (2005). A flexible framework for evaluating the socio-cultural impacts of a (small) festival. International Journal of Event Management Research, 1(1), 66-77.

Smith, A. (2014). Leveraging sport mega-events: New model or convenient justification? Journal of Policy Research in Tourism, Leisure and Events, 6(1), 15-30.

Stanojlović, A., Ćurčić, N., \& Pavlović, N. (2010). Tourism valorisation of site "Lazar's town" in Kruševac. Journal of the Geographical Institute „Jovan Cvijic" "SASA, 60(2), 77-92.

Tang, Q., \& Turco, D.M. (2001). Spending behaviors of event tourists. Journal of Convention \& Exhibition Management, 3(2), 33-40.

Tichaawa, T.M., \& Bob, U. (2015). Leveraging mega-events beyond the host nation: A case study of the 2010 FIFA World Cup African Legacy Programme in Cameroon and Nigeria. Leisure Studies, 34(6), 742-757.

Wills, J. (2001). Just, vibrant and sustainable communities: A framework for progressing and measuring community wellbeing, Townsville: Local Government Community Services of Australia.

Woods, M. (2003). Deconstructing rural protest: The emergence of a new social movement. Journal of Rural Studies, 19(3), 309-325. 